MATEC Web of Conferences 22,01046 (2015)

DOI: $10.1051 /$ matec conf/ 20152201046

(C) Owned by the authors, published by EDP Sciences, 2015

\title{
Research on Detection and Resolution of Resource Conflict of Virtual Cell Considering New Task Insertion
}

\author{
Wenming Han* \& Di Tong \\ School of Economics and Management, Jiangsu University of Science \& Technology, Zhenjiang, Jiangsu, China
}

\begin{abstract}
Specific to dynamic adjustment of initial scheduling of virtual cell with new task insertion, we use Bayesian network to detect resource conflict process which may appear in virtual cell due to contention of production tasks on finite resources within specified time period, and then adopt critical chain method to resolute resource conflict based on priority of virtual cell and priority of process. At last, the feasibility and effectiveness of proposed methods through case study are verified.
\end{abstract}

Keywords: virtual cell; new task insertion; detection and resolution of resource conflict; Bayesian network; critical chain

\section{INTRODUCTION}

As a new development of cell manufacturing mode, virtual cell production is an advanced production \& manufacturing method which has gained increasingly attention in recent years. Virtual manufacturing cell is to cluster production tasks into task family according to similarity of production tasks, and to select necessary equipment from alternative resource bank with due consideration of constraint condition for production, thus to develop logically correlated virtual dynamic entities with no necessity to change physical layout of equipment. Virtual cell has overcome limitation of traditional cell production, and it is able to respond the ever-changing market quickly, and has become an effective approach to realize production of multiple varieties in small batches.

In actual production, there are often some random events (increase of tasks, lack of raw materials, and equipment fault, and so on) which have disturbed production order. "New task insertion" is applied specifically to study the impact of disturbance events on virtual cell scheduling. Virtual cell has resource and time sharing mechanism, and occasion that production tasks use a common resource within certain time period simultaneously may occur within and between virtual cells. With established resources and capacity during specified time, there exists resource conflict in case existing resource fails to meet production demand when new task is inserted, and it is necessary to adjust scheduling dynamically to eliminate conflicts.

Currently, resource conflict is detected mostly depending on methods such as Petri Nets ${ }^{[2]}$, Time Petri Nets $^{[3]}$ and Constraint Unsatisfiable ${ }^{[4]}$, and eliminated depending on Reasoning ${ }^{[5]}$, Constraint ${ }^{[6]}$ and Collaboration $^{[7]}$, and so on. These methods can only be applied to project management, concurrent engineering and multi-agent system, and so on. However, resource in virtual cells is no longer limited to a particular vir-

*Corresponding author: wlmh63@163.com tual cell, and new task insertion has also increased complexity of conflict, and thus there is a certain limitation for method above to be applied to virtual cell. Therefore, this article presents a resource conflict detection method based on Bayesian network, an uncertain causal association model which is not only suitable to express complicated relation of attributes related with disturbance events, but also suitable to describe logic uncertainty between attribute polymorphism and attributes. Meanwhile, critical chain method is used to resolute resource conflict based on priority of virtue cell and priority of process, and this method takes full consideration of bottleneck resources in production system to optimize configuration of sharing resources between each task through critical chain coordination mechanism, thus to reduce adverse effect of disturbance factors on production.

\section{RESOURCE CONFLICT DETECTION OF VIRTUAL CELL BASED ON BAYESIAN NETWORK}

Bayesian network is a graph pattern used to describe dependency of data variables by directed acyclic graph, among which one node represents one attribute or variable and directed edge among nodes represents probabilistic dependency relationship ${ }^{[8]}$ between attributes or variables. Closely integrating probability theory and graph theory, it can not only reveal question researched in an intuitive manner, but also shrink complexity of model expression and reasoning.

There are three basic structures among nodes in Bayesian network, that is, $X_{i} \rightarrow X_{j} \rightarrow X_{k}, X_{i} \leftarrow X_{j} \rightarrow X_{k}$ and $X_{i} \rightarrow X_{j} \leftarrow X_{k}$ respectively. $X=\left(t_{s}, M_{i}, t_{f}\right)$ represents parameter triple of nodes. Among which, $t_{s}$ represents start time, $M_{i}$ represents used resources, and $t_{f}$ represents finish time. First, use Bayesian network to draw up original production scheduling according to the 


\section{MATEC Web of Conferences}

sequence and parameter triple of nodes. Second, list out resource-sharing working set $\mathrm{Mi}=\left(\mathrm{X}_{\mathrm{i}}, \mathrm{X}_{\mathrm{j}}, \mathrm{X}_{\mathrm{k}}\right)$ based on types of resources used by nodes in Bayesian network graph. With established resources and capacity during specified time, delete resource-sharing working set in case of no resource conflict when existing resource meets production demand; while output resource-sharing working set in case of resource conflict when existing resource fails to meet production demand.

Figure 1 indicates that resource conflict exists between virtual cell processes when new task is inserted. Within time interval $\left[t_{s}, t_{f}\right], X_{i j}$ and $X_{m n}$ both need to use finite resource $M$, in which, $X_{i j}$ represents the $j$ th task of virtual cell $\mathrm{i}, t^{i j}{ }_{s}$ represents start time for the jth task of virtual cell i, M represents resource used in the jth task of virtual cell $\mathrm{i}$, and $t^{i j} f$ represents finish time for the jth task of virtual cell i. $X_{m n}$ represents the nth task of virtual cell $\mathrm{m}, t^{m n}{ }_{s}$ represents start time for the nth task of virtual cell $\mathrm{m}$, and $t^{m n}{ }_{f}$ represents finish time of the nth task of virtual cell $\mathrm{m}$. In case that $i=m$, resource conflict exists within virtual cell; in case that $i \neq m$, resource conflict exists between virtual cells.

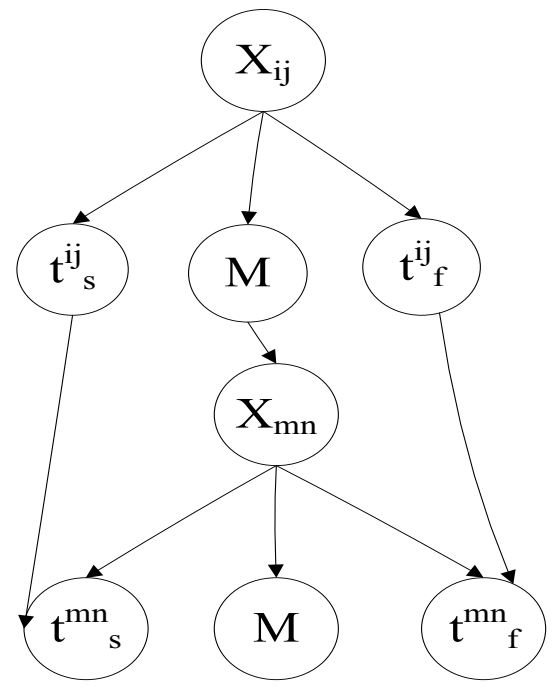

Figure1. Resource Conflict between Virtual Cell Processes

3 RESOURCE CONFLICT RESOLUTION OF VIRTUAL CELL BASED ON CRITICAL CHAIN

\subsection{Determination of critical chain}

First, calculate the earliest start time $E S T_{i}, i=1,2 \ldots . I$ and the earliest finish time $E F T_{i}, i=1,2, \ldots, I$ for each task according to original production scheduling; second, reversely calculate the latest start time $L S T_{i}, i=1,2, \ldots, I$ and the latest finish time $L F T_{i}, i=1,2, \ldots I$ for each task. In case that $E S T_{i}=L S T_{i}, i$ belongs to working set in critical chain; otherwise $i$ does not belong to working set in critical chain. At last, output process set of critical chain.

\subsection{Strategy for conflict resolution within virtual cell based on priority}

a. Critical chain process and non-critical chain process: process on critical chain enjoys distribution priority of sharing resources.

b. Priority of other processes: take overall consideration of impact of subsequent process number of conflict process as well as summation of delay time and continuous manufacturing time of conflict process on the whole cell. Formula (1) represents priority value of critical chain process; formulate (2) represents priority value of non-critical chain process. Whichever conflict process has the larger value has the deeper impact on the production scheduling, and the process enjoys distribution priority of sharing resources.

$E_{1}=\frac{1}{2} \bullet \frac{O(i, j)}{O^{\prime}(i, j)}+\frac{1}{2} \bullet \frac{T(i, j)}{T^{\prime}(i, j)}$

$E_{1}=\frac{1}{2}\left(\frac{1}{2} \bullet \frac{O(i, j)}{O^{\prime}(i, j)}+\frac{1}{2} \bullet \frac{T(i, j)}{T^{\prime}(i, j)}\right)$

In which, $O(i, j)$ represents number of subsequent manufacturing process of conflict process; $O^{\prime}(i, j)$ represents total number for subsequent manufacturing process of the whole cell; $T(i, j)$ represents summation of delay time and continuous processing time of process; $T^{\prime}(i, j)$ represents total time for subsequent manufacturing process of the whole cell.

\subsection{Strategy for conflict resolution between virtual cells based on priority}

Specific to resolution of resource conflict between virtual cells, this article provides a measuring formula $\mathrm{F}=0.5 \phi+0.5 \mathrm{E}_{1}$, which takes two factors into account: (1) priority $\phi$ of virtual cell, in which $\phi=\alpha \bullet \beta$, $\alpha$ represents delay time due to resource constraint, $\beta$ represents cost allowance due to delay of virtual cell every hours; (2) priority $E$ of conflict process in its own virtual cell. Whichever has the larger value of $\mathrm{F}$ has the higher integrated priority, and enjoys priority of resources.

\subsection{Buffer setting}

Root variance method is used in this article to set buffer size, to calculate buffer value by quadratic sum radication of cut safety time of process, and this concept also accords with superposition of undetermined time as is shown in formula (3) and formula (4):

$P B=\sqrt{\sum_{i=1}^{n}\left(D_{i}-d_{i}\right)^{2}} i \in C C, i=1,2, \mathrm{~K}, n$ 


$$
F B=\sqrt{\sum_{i=1}^{n}\left(D_{i}-d_{i}\right)^{2}} i \in N C C, i=1,2, \mathrm{~K}, n
$$

In which, $D_{i}$ represents conservative estimated time of process $i ; d_{i}$ represents the most probable estimated time of process $i ; i \in C C$ represents that process $i$ is on the critical chain while $i \in N C C$ represents that process $i$ is not on the critical chain.

\section{CASE ANALYSIS}

\subsection{Case description}

Pipe manufacturing workshop is a significant production department of shipbuilding enterprise. Labor hour of ship pipe accounts for $40 \%-45 \%$ of overall working quantity for shipping out, therefore pipe manufacturing has a large impact on the whole production cycle of ship. Meanwhile, virtual cell production is appropriate for ship considering complexity, multiple variety, small batch and large quantity of its pipeline. Therefore, we will take operation of certain pipe manufacturing team of one ship factory in Chinese mainland as an example to verify effectiveness of proposed method in the following passage.

At present, there are two virtual cells, six pipe fittings and twelve kinds of equipment in the manufacturing workshop. Original virtual cell $\mathrm{I}\left(\mathrm{VC}_{1}\right)$ includes parts families of $\mathrm{P}_{1}, \mathrm{P}_{2}$ and $\mathrm{P}_{3}$, and $1 \mathrm{M}_{1}, 2 \mathrm{M}_{4}, 1 \mathrm{M}_{7}, 1$
$\mathrm{M}_{8}$ and $1 \mathrm{M}_{10}$ of equipment group; original virtual cell II $\left(\mathrm{VC}_{2}\right)$ includes parts families of $\mathrm{P}_{4}, \mathrm{P}_{5}$ and $\mathrm{P}_{6}$, and 2 $\mathrm{M}_{2}, 2 \mathrm{M}_{6}, 1 \mathrm{M}_{9}, 1 \mathrm{M}_{11}$ and $1 \mathrm{M}_{12}$ of equipment group. Manufacturing quantities for the six pipe fittings are all of ten, with manufacturing route being $\mathrm{M}_{1}$ (5.2)-- $\mathrm{M}_{4}(6.8)--\mathrm{M}_{7}$ (4.7) for $\mathrm{P}_{1} ; \mathrm{M}_{1}(6.8)--\mathrm{M}_{4}(8)--\mathrm{M}_{8}$ (6.3)--- $\mathrm{M}_{10}(7)$ for $\mathrm{P}_{2} ; \mathrm{M}_{4}(12)--\mathrm{M}_{8}(8)--\mathrm{M}_{10}(8.5)$ for $\mathrm{P}_{3}$; $\mathrm{M}_{2}$ (43.4) -- $\mathrm{M}_{6}(24.6)--\mathrm{M}_{9}(12)--\mathrm{M}_{11}(12.6)$ for $\mathrm{P}_{4} ; \mathrm{M}_{2}$ (68.6)--- $\mathrm{M}_{6}(30)$-- $\mathrm{M}_{9}(13.2)--\mathrm{M}_{11}(13.3)-\mathrm{M}_{11}(18.5)$ for $\mathrm{P}_{5}$ and $\mathrm{M}_{2}(80)--\mathrm{M}_{6}(32)--\mathrm{M}_{9}(16.2)--\mathrm{M}_{11}$ (13.8) for $\mathrm{P}_{6}$. Numbers in the bracket represent manufacturing time for a pipe fitting on corresponding equipment. Time unit in the following passage are of minute.

During production, there are four urgent pipe fittings (NP1, NP2, NP3, NP4) to be inserted in production, with insertion time of $50,300,350$ and $840 \mathrm{~min}$ and manufacturing routes being $\mathrm{M}_{1}$ (5.5)--- $\mathrm{M}_{4}(7)--\mathrm{M}_{7}$ (5)-- $\mathrm{M}_{10}(4.5)$ for $\mathrm{NP}_{1}, \mathrm{M}_{2}(50)--\mathrm{M}_{6}(26)--\mathrm{M}_{9}(12.5)$ for $\mathrm{NP}_{2} ; \mathrm{M}_{3}(18)--\mathrm{M}_{5}(16)--\mathrm{M}_{9}(10)--\mathrm{M}_{11}(11.4)$ for $\mathrm{NP}_{3}$ and $\mathrm{M}_{3}(48)--\mathrm{M}_{5}(25)-\mathrm{M}_{10}(12.2)--\mathrm{M}_{12}(16)$ for $\mathrm{NP}_{4}$ respectively. According to method in reference ${ }^{[9]}$ used to measure similarity between new task and original production unit, insert new pipe fitting $\mathrm{NP}_{1}$ into $\mathrm{VC}_{1}$ and new pipe fitting $\mathrm{NP}_{2}$ into $\mathrm{VC}_{2}$, reconstruct $\mathrm{VC}_{3}$ with new pipe fitting $\mathrm{NP}_{2}$ and $\mathrm{NP}_{3}$, and provide initial scheduling of the three virtual cells $\left(\mathrm{NVC}_{1}, \mathrm{NVC}_{2}, \mathrm{NVC}_{3}\right)$ after new task insertion, which are shown in Table 1, Table 2 and Table 3 respectively.

Table 1. Initial Scheduling of New Virtual Cell I $\left(\mathrm{NVC}_{1}\right)$ after New Task Insertion

\begin{tabular}{llllll}
\hline Operation & $\begin{array}{l}\text { Workpiece/ } \\
\text { process/equipment }\end{array}$ & Time period & Operation & $\begin{array}{l}\text { Workpiece/ } \\
\text { process/equipment }\end{array}$ & Time period \\
\hline 1 & $\mathrm{P}_{1}-1-\mathrm{M}_{1}$ & {$[0,52]$} & 2 & $\mathrm{P}_{3}-1-\mathrm{M}_{4}$ & {$[0,120]$} \\
3 & $\mathrm{NP}_{1}-1-\mathrm{M}_{1}$ & {$[50,105]$} & 4 & $\mathrm{P}_{2}-1-\mathrm{M}_{1}$ & {$[52,120]$} \\
5 & $\mathrm{P}_{1}-2-\mathrm{M}_{4}$ & {$[52,120]$} & 6 & $\mathrm{P}_{1}-3-\mathrm{M}_{7}$ & {$[120,167]$} \\
7 & $\mathrm{NP}_{1}-2-\mathrm{M}_{4}$ & {$[120,190]$} & 8 & $\mathrm{P}_{2}-2-\mathrm{M}_{4}$ & {$[120,200]$} \\
9 & $\mathrm{P}_{3}-2-\mathrm{M}_{8}$ & {$[120,200]$} & 10 & $\mathrm{NP}_{1}-3-\mathrm{M}_{7}$ & {$[190,240]$} \\
11 & $\mathrm{P}_{2}-3-\mathrm{M}_{8}$ & {$[200,263]$} & 12 & $\mathrm{P}_{3}-3-\mathrm{M}_{10}$ & {$[200,285]$} \\
13 & $\mathrm{NP}_{1}-4-\mathrm{M}_{10}$ & {$[240,285]$} & 14 & $\mathrm{P}_{2}-4-\mathrm{M}_{10}$ & {$[285,355]$} \\
\hline
\end{tabular}

\begin{tabular}{|c|c|c|c|c|c|}
\hline Operation & $\begin{array}{l}\text { Workpiece/ } \\
\text { process/equipment }\end{array}$ & Time period & Operation & $\begin{array}{l}\text { Work- } \\
\text { piece/process/equipment }\end{array}$ & Time period \\
\hline 1 & $\mathrm{P}_{4}-1-\mathrm{M}_{2}$ & {$[0,434]$} & 2 & $\mathrm{P}_{6}-1-\mathrm{M}_{2}$ & {$[0,800]$} \\
\hline 3 & $\mathrm{NP}_{2}-1-\mathrm{M}_{2}$ & {$[300,800]$} & 4 & $\mathrm{P}_{5}-1-\mathrm{M}_{2}$ & {$[434,1120]$} \\
\hline 5 & $\mathrm{P}_{4}-2-\mathrm{M}_{6}$ & {$[434,680]$} & 6 & $\mathrm{P}_{4}-3-\mathrm{M}_{9}$ & {$[680,800]$} \\
\hline 7 & $\mathrm{P}_{4}-4-\mathrm{M}_{11}$ & {$[800,926]$} & 8 & $\mathrm{NP}_{2}-2-\mathrm{M}_{6}$ & {$[800,1060]$} \\
\hline 9 & $\mathrm{P}_{6}-2-\mathrm{M}_{6}$ & {$[800,1120]$} & 10 & $\mathrm{NP}_{2}-3-\mathrm{M}_{9}$ & {$[1060,1185]$} \\
\hline 11 & $\mathrm{P}_{6}-3-\mathrm{M}_{9}$ & {$[1120,1282]$} & 12 & $\mathrm{P}_{5}-2-\mathrm{M}_{6}$ & {$[1120,1420]$} \\
\hline 13 & $\mathrm{P}_{6}-4-\mathrm{M}_{11}$ & {$[1282,1420]$} & 14 & $\mathrm{P}_{5}-3-\mathrm{M}_{9}$ & {$[1420,1552]$} \\
\hline 15 & $\mathrm{P}_{5}-4-\mathrm{M}_{11}$ & {$[1552,1685]$} & 16 & $\mathrm{P}_{5}-5-\mathrm{M}_{12}$ & {$[1685,1870]$} \\
\hline
\end{tabular}


MATEC Web of Conferences

\begin{tabular}{|c|c|c|c|c|c|}
\hline Operation & $\begin{array}{l}\text { Workpiece/ } \\
\text { process/equipment }\end{array}$ & Time period & $\begin{array}{l}\text { Opera- } \\
\text { tion }\end{array}$ & $\begin{array}{l}\text { Workpiece/ } \\
\text { process/equipment }\end{array}$ & Time period \\
\hline 1 & $\mathrm{NP}_{3}-1-\mathrm{M}_{3}$ & {$[350,530]$} & 2 & $\mathrm{NP}_{3}-2-\mathrm{M}_{5}$ & {$[530,690]$} \\
\hline 3 & $\mathrm{NP}_{3}-3-\mathrm{M}_{9}$ & {$[6900,790]$} & 4 & $\mathrm{NP}_{3}-4-\mathrm{M}_{10}$ & {$[790,904]$} \\
\hline 5 & $\mathrm{NP}_{4}-1-\mathrm{M}_{3}$ & {$[840,1320]$} & 6 & $\mathrm{NP}_{4}-2-\mathrm{M}_{5}$ & {$[1320,1570]$} \\
\hline 7 & $\mathrm{NP}_{4}-3-\mathrm{M}_{10}$ & {$[1570,1692]$} & 8 & $\mathrm{NP}_{4}-4-\mathrm{M}_{12}$ & {$[1692,1852]$} \\
\hline
\end{tabular}

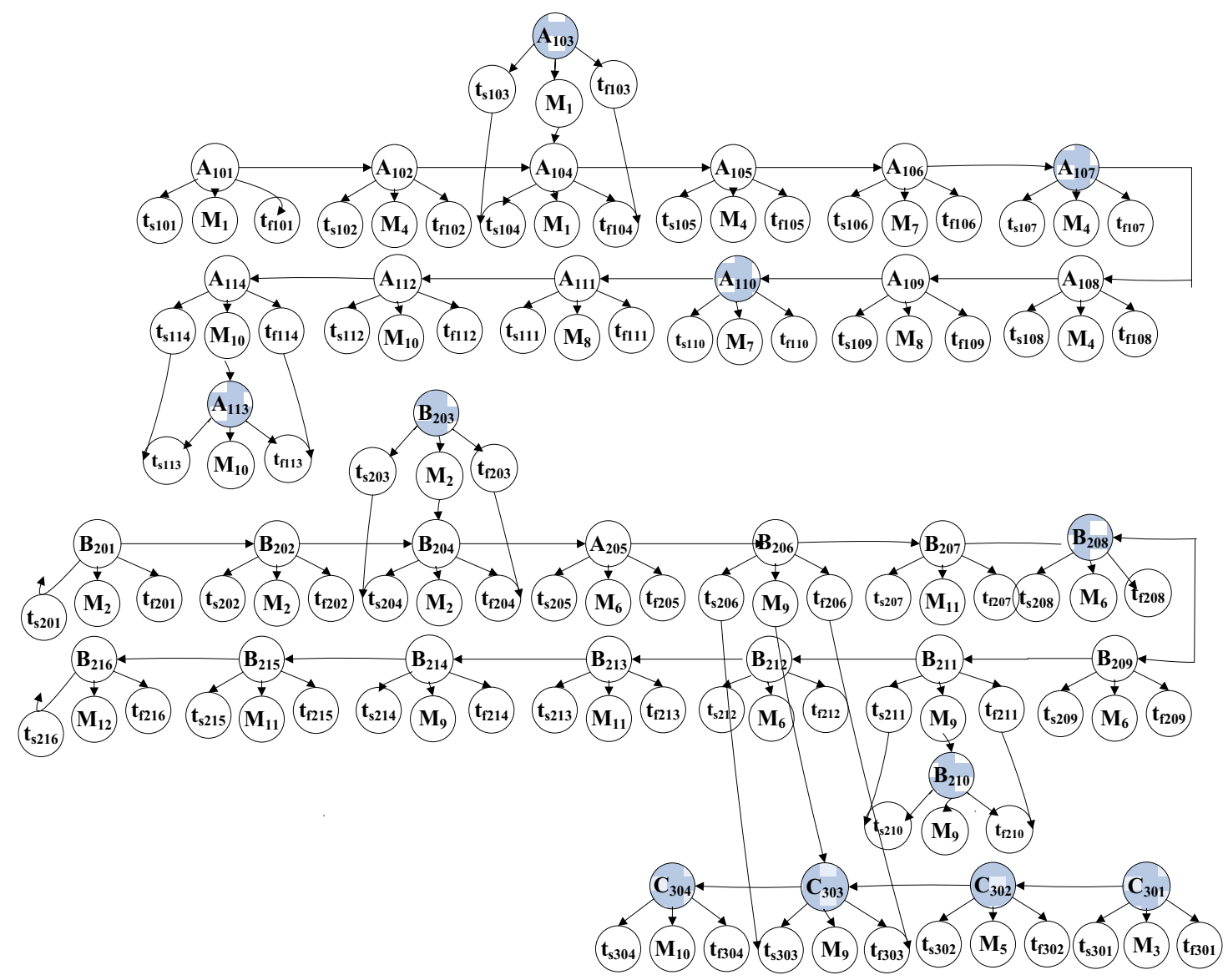

Figure 2. Bayesian Network Graph after New Task Insertion

Based on the three scheduling tables of virtual cell, draw up Bayesian network graph, in which dash area represents each process for new pipe fitting, see Figure 2. As shown in Figure 2, there are six pairs of resource conflict processes, that is: (1) $\mathrm{A}_{103}$ and $\mathrm{A}_{104}$ belong to $\mathrm{M}_{1}$ conflict in $\mathrm{NVC}_{1} ;(2) \mathrm{A}_{113}$ and $\mathrm{A}_{114}$ belong to $\mathrm{M}_{10}$ conflict in $\mathrm{NVC}_{1}$; (3) $\mathrm{B}_{203}$ and $\mathrm{B}_{204}$ belong to $\mathrm{M}_{2}$ conflict in $\mathrm{NVC}_{2}$; (4) $\mathrm{B}_{210}$ and $\mathrm{B}_{211}$ belong to $\mathrm{M}_{9}$ conflict in $\mathrm{NVC}_{2}$; (5) $\mathrm{B}_{206}$ and $\mathrm{C}_{303}$ belong to $\mathrm{M}_{9}$ conflict between $\mathrm{NVC}_{2}$ and $\mathrm{NVC}_{3}$; (6) $\mathrm{B}_{216}$ and $\mathrm{C}_{308}$ belong to $\mathrm{M}_{12}$ conflict between $\mathrm{NVC}_{2}$ and $\mathrm{NVC}_{3}$.

According to determination method of critical chain, following critical chains are obtained, that is, $\mathrm{NVC}_{1}$ critical chain of $\mathrm{A}_{102} \rightarrow \mathrm{A}_{105} \rightarrow \mathrm{A}_{107} \rightarrow \mathrm{A}_{108} \rightarrow \mathrm{A}_{111} \rightarrow \mathrm{A}_{114}$

with $\mathrm{PB}=10 ; \quad \mathrm{NVC}_{1}$ non-critical chain of $\mathrm{A}_{101} \rightarrow \mathrm{A}_{103} \rightarrow \mathrm{A}_{104} \rightarrow \mathrm{A}_{106} \rightarrow \mathrm{A}_{109} \rightarrow \mathrm{A}_{110} \quad \rightarrow \mathrm{A}_{112} \rightarrow \mathrm{A}_{113}$ with $\mathrm{FB}=12$; $\quad \mathrm{NVC}_{2} \quad$ critical chain of $\mathrm{B}_{202} \rightarrow \mathrm{B}_{203} \rightarrow \mathrm{B}_{204} \rightarrow \mathrm{B}_{212} \rightarrow \mathrm{B}_{214} \rightarrow \mathrm{B}_{215} \rightarrow \mathrm{B}_{216} \quad$ with $\mathrm{PB}=76$; $\quad \mathrm{NVC}_{2}$ non-critical chain of $\mathrm{B}_{201} \rightarrow \mathrm{B}_{205} \rightarrow \mathrm{B}_{206} \rightarrow \mathrm{B}_{207} \rightarrow \mathrm{B}_{208} \rightarrow \mathrm{B}_{209} \rightarrow \mathrm{B}_{210} \rightarrow \mathrm{B}_{211} \rightarrow$ $\mathrm{B}_{213}$ with $\mathrm{FB}=50 ; \quad \mathrm{NVC}_{3}$ critical chain of $\mathrm{C}_{301} \rightarrow \mathrm{C}_{305} \rightarrow \mathrm{C}_{306} \rightarrow \mathrm{C}_{307} \rightarrow \mathrm{C}_{308}$ with $\mathrm{PB}=0$; and $\mathrm{NVC}_{3}$ non-critical chain of $\mathrm{C}_{302} \rightarrow \mathrm{C}_{303} \rightarrow \mathrm{C}_{304}$ with $\mathrm{FB}=11$.

Meanwhile, following conclusions are obtained based on conflict resolution strategies (selecting cost allowance $\beta$ as 3): (1) Process priority value of $\mathrm{A}_{103}$ and $\mathrm{A}_{104}$ are 0.1112 and 0.1218 respectively, that is, $\mathrm{A}_{104}$ enjoys priority; (2) $\mathrm{A}_{113}$ and $\mathrm{A}_{114}$ belong to 
ICETA 2015

Table 4. Final Scheduling of New Virtual Cell I $\left(\mathrm{NVC}_{1}\right)$ after New Task Insertion

\begin{tabular}{llllll}
\hline Operation & $\begin{array}{l}\text { Workpiece/ } \\
\text { process/equipment }\end{array}$ & Time period & Operation & $\begin{array}{l}\text { Workpiece/ } \\
\text { process/equipment }\end{array}$ & Time period \\
\hline 1 & $\mathrm{P}_{1}-1-\mathrm{M}_{1}$ & {$[0,52]$} & 2 & $\mathrm{P}_{3}-1-\mathrm{M}_{4}$ & {$[0,120]$} \\
3 & $\mathrm{P}_{2}-1-\mathrm{M}_{1}$ & {$[52,120]$} & 4 & $\mathrm{NP}_{1}-1-\mathrm{M}_{1}$ & {$[120,175]$} \\
5 & $\mathrm{P}_{1}-2-\mathrm{M}_{4}$ & {$[52,120]$} & 6 & $\mathrm{P}_{1}-3-\mathrm{M}_{7}$ & {$[120,167]$} \\
7 & $\mathrm{P}_{2}-2-\mathrm{M}_{4}$ & {$[120,200]$} & 8 & $\mathrm{P}_{3}-2-\mathrm{M}_{8}$ & {$[120,200]$} \\
9 & $\mathrm{NP}_{1}-2-\mathrm{M}_{4}$ & {$[175,245]$} & 10 & $\mathrm{NP}_{1}-3-\mathrm{M}_{7}$ & {$[245,295]$} \\
11 & $\mathrm{P}_{2}-3-\mathrm{M}_{8}$ & {$[200,263]$} & 12 & $\mathrm{P}_{3}-3-\mathrm{M}_{10}$ & {$[200,285]$} \\
13 & $\mathrm{P}_{2}-4-\mathrm{M}_{10}$ & {$[285,355]$} & 14 & $\mathrm{NP}_{1}-4-\mathrm{M}_{10}$ & {$[355,400]$} \\
\hline
\end{tabular}

Table 5. Final Scheduling of New Virtual Cell II $\left(\mathrm{NVC}_{2}\right)$ after New Task Insertion

\begin{tabular}{llllll}
\hline Operation & $\begin{array}{l}\text { Workpiece/ } \\
\text { process/equipment }\end{array}$ & Time period & Operation & $\begin{array}{l}\text { Workpiece/ } \\
\text { process/equipment }\end{array}$ & Time period \\
\hline 1 & $\mathrm{P}_{4}-1-\mathrm{M}_{2}$ & {$[0,434]$} & 2 & $\mathrm{P}_{6}-1-\mathrm{M}_{2}$ & {$[0,800]$} \\
3 & $\mathrm{P}_{4}-2-\mathrm{M}_{6}$ & {$[434,680]$} & 4 & $\mathrm{P}_{5}-1-\mathrm{M}_{2}$ & {$[434,1120]$} \\
5 & $\mathrm{P}_{4}-3-\mathrm{M}_{9}$ & {$[790,910]$} & 6 & $\mathrm{P}_{6}-2-\mathrm{M}_{6}$ & {$[800,1120]$} \\
7 & $\mathrm{NP}_{2}-1-\mathrm{M}_{2}$ & {$[800,1300]$} & 8 & $\mathrm{P}_{4}-4-\mathrm{M}_{11}$ & {$[910,1036]$} \\
9 & $\mathrm{P}_{6}-3-\mathrm{M}_{9}$ & {$[1120,1282]$} & 10 & $\mathrm{P}_{5}-2-\mathrm{M}_{6}$ & {$[1120,1420]$} \\
11 & $\mathrm{P}_{6}-4-\mathrm{M}_{11}$ & {$[1282,1420]$} & 12 & $\mathrm{NP}_{2}-2-\mathrm{M}_{6}$ & {$[1300,1560]$} \\
13 & $\mathrm{P}_{5}-3-\mathrm{M}_{9}$ & {$[1420,1552]$} & 14 & $\mathrm{P}_{5}-4-\mathrm{M}_{11}$ & {$[1552,1685]$} \\
15 & $\mathrm{NP}_{2}-3-\mathrm{M}_{9}$ & {$[1560,1685]$} & 16 & $\mathrm{P}_{5}-5-\mathrm{M}_{12}$ & {$[1852,2037]$} \\
\hline
\end{tabular}

non-critical chain process and critical chain process, that is, $A_{114}$ enjoys priority; (3) Process priority value of $\mathrm{B}_{203}$ and $\mathrm{B}_{204}$ are 0.185 and 0.4008 respectively, that is, $B_{204}$ enjoys priority; (4) Process priority value of $\mathrm{B}_{210}$ and $\mathrm{B}_{211}$ are 0.0826 and 0.1141 respectively, that is, $\mathrm{B}_{211}$ enjoys priority; (5) Integrated priority value of $\mathrm{B}_{206}$ and $\mathrm{C}_{303}$ are 0.2514 and 0.3233 respectively, that is, $\mathrm{C}_{303}$ enjoys priority; (6)Integrated priority value of $B_{216}$ and $C_{303}$ are 0.4176 and 0.445 respectively, that is, $\mathrm{C}_{303}$ enjoys priority. Scheduling is readjusted after conflict resolution, that is, final scheduling of $\mathrm{NVC}_{1}$ is shown in Table 4 ; final scheduling of $\mathrm{NVC}_{2}$ is shown in Table 5; while final scheduling of $\mathrm{NVC}_{3}$ is its initial scheduling.

Through comparison of initial scheduling and final scheduling, it is obtained that master production plans are 2236 minutes and 2037 minutes respectively, that is, the latter is 199 minutes less than the former; meanwhile, total time used by the two plans on 12 equipment are 15047 minutes and 13827 minutes respectively, that is, the latter is 1220 minutes less than the former, and thus has effectively improved production efficiency, and has further verified feasibility and effectiveness of proposed method.

\section{CONCLUSION}

This paper mainly studies impact of new task insertion, the disturbance event, on scheduling of original virtual cell. New task insertion has disturbed production plan of original virtual cell, and resource conflict may occur in specific time period when production tasks need to use one restricted resource together. Therefore, this article finds out location of resource conflict based on
Bayesian network, and adopts critical chain method to resolve resource conflict inside and between virtual cells in combination with priority method. Scheduling after dynamic adjustment not only enables orderly completion of new task and original task, but also improves production efficiency and shortens production cycle greatly.

\section{ACKNOWLEDGEMENTS}

This work was financially supported by National Natural Science Foundation of China (NSFC) (71271105) and Humanities and Social Sciences Planning Fund of Ministry of Education (12YJA630036).

\section{REFERENCES}

[1] Hassan Rezazadeha, Reza Mahini. \& Mahdi Zarei. 2011. Solving a dynamic virtual cell formation problem by linear programming embedded particle swarm optimization algorithm. Applied Soft Computing 11:3160-3169.

[2] Song Haiquan, Guo Jin. \& Li Yao. 2013. Confliction resolution $[\mathrm{J}]$ of distributed system based on Petri Nets Computer Engineering and Design, 34 (4): 1351-1355.

[3] Zhou Hang, Huang Zhiqiu. Hu Jun. \& Zhu Yi. 2009. Resource conflict detection of real-time system based on Time Petri Nets. Journal of Computer Research and Development, 46 (9): 1578-1585.

[4] Xin W. Chen. \& Shimon Y. 2012. Nof. Conflict and error prevention and detection in complex networks. Automatic $48: 770-778$.

[5] Hou Junming, Su Chong. Liang Shuang. \& Wang Wanshan. 2009. Research on conflict resolution of col- 


\section{MATEC Web of Conferences}

laborative design with fuzzy case-based reasoning method. Journal of Chongqing University of Posts and Telecommunications (Natural Science Edition). 21(2): 314-322.

[6] Elloumi S. \& Fortemps P. 2010. A hybrid rank-based evolutionary algorithm applied to multi-mode resource-constrained project scheduling problem. European Journal of Operational Research, 205(1): 31-41.

[7] Jiang Guorui, Duan Xiaomin. \& Zhang Hanlin. 2010. Supply chain collaboration plan based on conflict detection. Computer Engineering. 36 (6): 247-249.

[8] Jon T. McCloskey, Robert J. Lilieholm. \& Christopher Cronan. 2011. Using Bayesian belief networks to identify potential compatibilities and conflicts between development and landscape conservation. Landscape and Urban Planning, 101: 190-203.

[9] Garbie I H, Parsaei H R. \& Leep H R. 2005. Introducing new parts into existing cellular manufacturing systems based on a novel similarity coefficient. International Journal of Production Research, 43 (5): 1007-1037. 